\title{
2000’li Yıllarda Kadın Öykücülerin Dili Üzerine Tespitler
}

\author{
ERTAN ÖRGEN*
}

\begin{abstract}
ÖZ
Türk edebiyatında kadın yazarların dili, uzun zaman erkek yazarların izinde gitmek durumunda kalmıştır. Kültürel, sosyolojik ve ekonomik değişmelerle birlikte kadın yazar sayısında 2000’li yıllarda görülen büyük artış, bu yazarların kendilerine mahsus bir dil bulup bulamadığı tartı̧̧masına uygun bir süreç yaratmıştır. Bu araştırmanın amacı, 2000’li yıllar Türk öyküsünde kadın diline ait bazı belirlemelerde bulunmak ve kadın yazarların kendilerine ait bir dil edinip edinemediklerini veya önceki alışkanlıklarını değiştirip değiştiremediklerini tartı̧̧maktır. Yazıda, dönemin önemli sayılabilecek yedi kadın öykücüsünün birer kitabı seçilerek bu metinler üzerinde konu incelenmiştir. Buna göre şefkat ve cinsellik başlıkları altında kadın öykücülerin diline yaklaşılmış, onların bir kadın gözüyle dünyayı ve insanı alışılmış dilden ne kadar farklı anlatıp anlatamadıkları ortaya konmaya çalışılmıştır.
\end{abstract}

Anahtar sözcükler: Kadın yazar ve dil, kadın öykücüler, 2000'li yıllar, merhamet, cinsellik

$\mathrm{E}$ debi dil, öncelikle insanlık hâllerinden yola çıkar. Dile bir cinsiyet atfedilmesi toplumsal cinsiyet gibi sonradandır. Buradan dil anlamında kadına bağlı bir edebiyat dili olup olmadığı sorununun tartışılması, öncelikle postmodern dünyanın çokseslilik, değişen cinsiyet algıları, kadının dille olan salt ilgisi gibi tartı̧ma alanları ile yakınlık gösterir. Bir başka ifadeyle, buna izin veren postmodern süreçteki çoksesliliktir. Bu yazının amacı, dünyaya ve insana cinsiyete bağlı bir tasarrufla bakma ve bunu ifade etme sorununun, kadının yazılı edebiyata katılmasıyla nereye vardığına ilişkin bazı çıkarsamalar yapmaktır. Çünkü Türk edebiyatında Tanzimat sonrası anlatılarda, kadını cinsine uygun biçimde konuşturma çok da başarılı değildir. Kadınlar, kurgunun parçası olarak aldıkları rollere uygun davranmışlar ve kendi dünyalarını

\footnotetext{
* Doç. Dr., Balıkesir Üniversitesi, Türkçe Eğitimi Bölümü/BALIKESİR

E-posta: eorgen@balikesir.edu.tr
} 
ifadede erkek yazarın tasarrufunda kalmışlardır (Ağaoğlu 2007: 374, Moran 1991: 36, Tanpınar 2006: 363). Değişen sosyal ve ekonomik şartlar kadın yazarı da yazılı kültürün içinde var kılmış, ürettikleri metinlerde konuşma, konuşturma biçimleri de zamanla gelişmiştir. Sözlü kültürde, masal dilinde anlatıcı olarak bulunan kadınsı dünya tasarımı veya şiirsel olarak ninni, mani, ağıt türlerindeki kadınsı dil, yazılı edebiyat içerisinde uzun bir yolculuk sonrası karş1lık bulmuştur. Bu makalede, 2000'li yıllarda kadın öykücü sayısındaki artışın bu dili bulmakla ve sınırlarını genişletmekle ilgisi, seçilmiş örnekler üzerinden tespit edilerek tartışılmaya çalışılacaktır. Bu konunun arka planında yer alan boşluk ise, Türk öykü ve romancılığındaki kadın yazarların, hem söylem hem de metin uzantısında dili nasıl kullandıklarının gelişim içerisinde incelenmemiş olmasıdır. Ancak bu durum kısmen sosyolojik bir izahla, kısmen de dönemlere ilişkin özet bilgilerle bir parça aydınlatılabilir.

\section{Türkiye'de Kadın ve Kadın Yazar}

Cumhuriyet döneminde kadına, siyasal ve sosyal yapıdan hareketle bakıldığında görülecek genel manzaranın konuyla bağlantılı zemini özetle şöyledir: Kurtuluş Savaşı'nda kadınların cephedeki önemli rolleri, Medeni Kanun (1926), oy hakkı (1934) gibi gelişmeler, kadına önemli bir alan tanımıştır. Ancak asıl durum, Şirin Tekeli'nin değerlendirmesiyle, kadının tarihsel ve toplumsal olarak kendini yeni rejime uygun "kurtulmuş kadınlar" biçimde tanımlamasıdır. Görece seçkinlik kazanılması nedeniyle kadınlar, bağımsız kadın hareketine ve feminist yaklaşımlara sırt çevirmişlerdir (1995: 30-32). $\mathrm{Bu}$ sosyolojik durum günümüz ekonomik verileriyle düşünüldüğünde gelişimin ulaştı̆̆ nokta tespit edilebilir. 2009 yilı verilerine göre kadınlarda, erkeklere oranla çok daha güçlü bir eğitim ve işgücü katılımı söz konusudur (İlkkaracan 2010: 23). Yine 1980 sonrası finansal liberalizasyonla birlikte hizmet sektöründe eğitimli kadın talebindeki istikrar sürmüştür (2010: 3132). Bu veriler bize kadının sosyal hayatta giderek alanını genişlettiğini ama yanı başında kendisine verilmiş bulunan statüyü koruduğunu ve onu çok fazla değiştirmeye çalışmadığını açıklar. Sosyal haklar konusunda 1998'de ailenin korunması, kadına şiddeti önleme; 2001'de ailenin reisi, velayet hakkı, mal ayrılığı rejimleri etrafındaki pozitif gelişmeler; 2004'te cinsel saldırı, töre cinayeti dolayısıyla kadının kanunlarla korunması önemli kazanımlar olarak kaydedilebilir.

Buradan yazı sanatına geçildiğinde benzer gelişmeler tespit edilmektedir. Kadının dönemler içerisinde şiir, düzyazı alanındaki varlığı sayısal olarak artmıştır. Genel bir tespitle Türk edebiyatında kadın yazar sayısının özellikle 1970 sonrasında arttığı gözlemlenir (Argunşah 2006: 39). Bu yazının esasını 
oluşturan kadın öykücülerin sayısındaki artış da hâliyle 1990 sonrasında çok daha fazladır. Türk öykücülüğünde 1990-2005 yıllarını kapsayan sosyolojik bir araştırmada, 1990'lı yıllarda bir patlamanın yaşandığı ve bu yıllarda kadın öykücülerin oranının yüzde otuz civarında olduğu tespit edilmiştir (Dündar 2007: 34-35). Aynı araştırmada örneklem zaman ve kitap sayısı açısından daraltıldığında, kadın öykücü oranının artış göstererek yüzde elliye ulaştığ söylenir (2007: 59). Türk romanı üzerine bir derleme çalı̧̧ması olan Edebiyatımızda Bireyselleşme Serüvenìnde onbeş erkek, onbeş kadın yazardan seçilmiş eserler üzerinde çeşitli sorulara cevap aranırken romanlardaki kadın karakterlerin yazma eylemine ilişkin şöyle bir sonuca varılır: "Yazarlık kadın kahramanlarda ele geçirilecek yeni bir alanken, erkeklerin sadece sürdürdüğü bir alan[dır]" (Akerson 2013: 204). Bütün bu gelişmeler, kadının yazarlık serüveninin yükselişini göstermektedir.

\section{Kadın ve Dil}

Türkçede, kadın yazarın cinsiyete bağlı, kendisine mahsus bir dili olup olmadığ1 ve bunu geliştirip geliştirmediği tanım ve kapsam olarak çok tartış1mamıştır. Doğallıkla Türk dilinin cinsiyet taşımayan yapısı da bunda özel bir yer tutar. Toplumsal cinsiyet olarak kadınla ilgili sözlük çalışmaları da henüz yeterli bir düzeye ulaşmamıştır. Kadın Argosu Sözlüğü başlıklı çalışma bir gizli dil olarak ilgi çekici sayılabilir; ancak sadece argoya dayanması, bu konu açısından bir eksiklik taşımaktadır. Konuşmada sesin renginden ve tonlamasından elde edilebilecek ayrım, yazıda kendisini örtmektedir. Kadının mutfakta veya hemcinsleriyle bir aradayken kendisini ifade etmesi, toplum içindeyken geri çekilmesi konuşma tercihi olarak daha açık bir belirtidir. Genel olarak bakıldığında, erkek diliyle kadın dilinin farkı belirlenmeye kalkışıldığında, "merhamet" ve "cinsellik" kategorileri uygun gözükmektedir. Bu tavırlardan ilki, kadını tanımlayan duygusallık, sosyal hayatta onu belirleyen annelik ve şefkat tarafidır. Kadın öykücünün dilinde bu tercih, uzun zaman çocuk anlatıcı ve bakış açısının kullanılmasıyla sürdürülmüştür. Süreç içinde bu durumun, yükselen yeni değerler eşliğinde, ergenliğe ve oradan da kadının doğal hâline doğru ilerlediği metinlere paralel olarak okunabilir. Çok seslilik, çoğulculuk, cinsiyetin homojenleşmesi kavramları kadının sesini rahatlatmış ve konuşma özgürlüğünü geliştirmiştir. İkinci tavır ise kadını erkekten ayıran kendi cinsiyetini, cinsellik açısından dile getirişidir. Bu çıkarsama, Batı'da özellikle feminist hareketin kalkış noktasıdır. Feminist hareketteki eve ve doğurganlığa itiraz, kadın dilini daha görünür kılmıştır. Bu gelişen süreçte, Türk yazarlarda da izleri görülen Batı kültür ve edebiyatındaki feminizm ve kadın dili tartışmalarının konuyla ilgili kısmını Jale Parla şöyle özetler: 
Hélène Cixous, Luce Irigaray erkek dilini işlemez hale getirmeyi amaçlar. Burada feminist hareket Derrida'nın yapıçözümcü yani anlam boşaltıcı yöntemini benimser. Kristeva, Rus biçimcilerinin edebiyat eserinin ancak yabancılaştırıp yadırgatarak etkili olacağı düşüncesine katılır ve avangard, psikopat, bebek dili diskurunu kullanarak egemen dil biçimini paramparça etmek ister. İşte Fransız feministleri Julia Kristeva’nın bu semiyotik başkaldırısından esinlenerek l'ecriture féministe'i tarif ettiler. (2004: 32)

Batıda Freud'un kadını ötekileştirmesini reddeden feministler, Lacan'dan yola çıkarak simgesel döneme kadar olan cinsiyetsizliği vurgulayıp Kristeva’nın anneyle çocuk arasındaki dil bağ1 vurgusuna yaslanarak eril tasarımı reddederler (Eagleton 2004: 228-232, Parla 2004: 32-33). Postmodern dönemeçte Batı literatürü, feminizmi tanımlarken ataerkilliğin ötesine geçildiği sonucunu çıkarır (Benhabib 1999: 282-286, Connor 2001: 340). Doğal olarak bu bilgi düzeyinin Türk edebiyatında birebir karşılıklarından değil, genel etkilerinden söz edilebilir.

\section{Türk Öyküsünde Kadın Yazar ve Dil}

Bu başlık altında Cumhuriyet dönemi Türk kadın öykücülerinin anlatım biçimlerine ve alışkanlıklarına bir çerçeve olarak değinilecektir. İlk kadın öykücüler olarak adlandırılabilecek listede, 1950'lere kadar genellikle erkeğin belirlediği kavramlara yaklaşmaya çalışan veya kadının tarihsel misyonu içerisinde incelik ve duygusallığın ağır bastığı isimler söz konusudur. Halide Edib ve Halide Nusret ilk sözü edilen durumun, Güzide Sabri ve Şükûfe Nihal ikinci grubun temsilcisi olarak anılabilir. Bu anlamda "[v]aroluş alanı evden, özel ve kamusal alana doğru genişleyen kadının, militan anlamda feminist söyleme ulaşması ve eril yazın tarafından marjinallikle suçlanması ancak 1960'lardan sonraya kalacaktır" (Hazer 2005: 46). Bu tespit, ilerleyen süreçte kadın öykücünün geldiği yeri gösterir. Marjinal sayılabilecek isimlere 1960 sonrası Leyla Erbil ve Sevgi Soysal örnek gösterilebilir. Onlar, toplumsal cinsiyeti reddeden ve kadına özel bir kimlik aktaran metinleri itibarıla bu kapsamdadır.

Erbil, yazarlığın gövdeyle değil, beyinle gerçekleştiğinin altını çizdikten sonra "bizden önce tek taraflı olarak erkeklerce örülmüş bulunan edebiyat düzeninde yerimizi almamız gerekiyor" (Karaca 2006: 202) önerisiyle daha çok yazarlık alanına ilişkin bir arayışı vurgular. Erbil ve kadın söylemi açısından bilinçdışı, kadın ve toplumsal cinsiyet uzantısında "Konuşmaklardan Bakan" öyküsüne değinilebilir. Öyküde kadının aşka dair kuşatılmışlığı, ona kendi saflı̆g içinde bakamayışı itiraz eden ve sorgulayan bir ifadeye sokulur:

Kişi aşk diye hür diye dilsiz ve çirkin olmayan ve ne olduklarını iyice bildiği kişilere de usunu, çağrışım gücünü, dip bilinç akışını yitirmeden, sırf 
açlık, sarhoşluk, yoksulluk ya da beğeni etkenlerinden sıyrılmış HANGİ ÖZGÜR SEVI'yi toplayabilirdi?(...) Ben ilkel ve gür bi kendini değiştirmeye, özgür seviye akmayı istiyordum. (2004: 52)

Erbil, modernist bir tavırla mevcut erkek egemen söyleyişe ve toplumsal cinsiyet dayatmalarına karşı çıkar.

1970’lerde ilk öykü kitabı yayımlanan Adalet Ağaoğlu, sivrilen bir kadın dili yaratmanın mahzuruna şöyle temas eder: "Salt kadın duyarlığımızla yazsaydık, romanlarımızda, hikâyelerimizde erkek eksik kalırdı. Çok 'erkekçe' yazsaydık, kadın silinmiş, yok edilmiş, daha kötüsü çarpıtılmış olurdu. Hayat da eksik ve çarpık yansırdı. Daha da kötüsü, insanı bir bütün olarak gören kendimizi unutmuş bulurduk" (1993: 25). Yazar, "Adi Suçlu” öyküsünde de bu tutumu örnekler. Öykü, apandisit ameliyatı olan bir kadının, ameliyat sonrası hastanede kaldığı günlerde kocası ve arkadaşlarının cezaevinde maruz kaldıkları ağır işkenceleri hatırlaması ve yanındaki yatakta kalan diğer hasta kadının basit dünyasına katlanamayıp onun kaşını patlatması üzerinedir. Politik yönelimleri olan ve etrafına, eşyaya, insanlara bilinçli olarak bakan kadın konuşur ve düşünürken entelektüel bir kişilik özelliği gösterir.

İnsan, gerçeği bulabilmek için seksen parça lafı bir ucundan çekip birbirine yapıştırmak zorunda kalıyor. Yine de peşin bilinenin dışında bütün bir yüz çımıyor ortaya. Biz dışarıdakiler de... İşte ancak körbağırsağa irin toplamayı biliyoruz. Çıkar çıkmaz Yavuz'a bir börek yapayım, içimizi başka nasil sustururuz? (2004: 23)

Burada kadın yazarın dili aşk, vatan temasının örtüsünü kaldırır ve yerine gerçeklik düşüncesini koyar. Yanı başında ise kadına mahsus "börek yapma”yı yine bir konum ve dolayisıyla dil tercihi olarak ihmal etmez.

Aynı dönemin önemli bir modernist öykücüsü olan Tomris Uyar, ayrıksı bir dil yaratma peşinde değildir. Merhametin, şefkatin dili onda çok açıktır. Yine Füruzan'ın şehre sıkışmış anne-kız veya yoksulluk üzerinden giriştiği anlatım da merhametin dile gelişidir.

1980 sonrası öyküde yer alan isimlerden Erendiz Atasü, kadının duygusal dil kullanmasını ataerkil kültürün erkeğe dayattığı yasakları, kadına yaşama hakkı vermesi ile ilgili görür. Bu açıdan kadının hem en güçlü hem en zayıf tarafı olarak duygularını gösterir. Kadın dili açısından bu vurgu önemsenecek bir içeriktir. Çünkü ona göre; sevinç, gözyaşı, korku, kaygı kadına yasak edilmemiştir (2006: 337). Yine 1980 kuşağından Ayfer Tunç, erkek eleştirmenlerin yakıştırdığı "kadınca duyarlık" tanımlamasının ancak kadına mahsus bir alanı işaret ettiğini dile getirir. Bu aynı zamanda dönemin kadın dili gelişimi hakkında önceki yargıların hâlâ hüküm sürdüğünü gösterir. Kendisi, bu yargıyı kırmak amacıyla öykülerinde erkek anlatıcıyı seçtiğini söylerken dildeki 
alışkanlığı da vurgulamış olur (Hazer 2005: 52-53). Önceki kuşağın siyasal, feminist, sosyal gerçekçi öykü tecrübeleri ve yazarlıkta aldıkları mesafe, 1980 sonrasındaki kadın yazarlara cesaret vermiş olur. Sonuç olarak, genel bir bakışla ilk öykücülerden 2000'lere kadar kadın yazarın erkek dünyası ile aynı sesle konuşmaktan kısmen karşı çıkmaya, büyük oranda ise yazar kimliği ile yer tutma çabasına doğru ilerlediği görülmektedir.

\section{0’li Yıllarda Kadın Öykücüler ve Kadın Dili}

Bu başlık altında 2000'li yıllarda ismi öne çıkan kadın yazarlardan yedisinin birer kitabı üzerinde kadın dili, yukarıda temas edilen temalar, beden, cinsellik, merhamet, çocukluk ve protesto başlıkları altında değerlendirilecektir. Seçilen öykü kitapları şunlardır: Sema Kaygusuz Sandık Lekesi (2000), Hatice Meryem Sinek Kadar Kocam Olsun, Başımda Bulunsun (2002), Sibel K. Türker Ağula (2007), Aslı Erdoğan Taş Bina ve Diğerleri (2009), Mukadder Gemici Asla Pes Etme (2011), Mihriban İnan Karatepe Aramızda (2012), Birgül Oğuz Hah (2012). İlgili kitaplardaki toplam elli dokuz öyküden bu konuya malzeme oluşturulabilecek mahiyetteki öyküler seçilmiştir.

\section{Beden}

İncelenen öykülerde ilk olarak kadın bedenine ait tasvir ve benzetmeler üzerinden yazarın kendisine ve hemcinsine nasıl baktığını ele alarak başlamak, dilde hazır formları aşıp aşamadıkları açısından bir fikir verecektir. Çünkü ilk feminist yazarların söyledikleri prensiplerden biri "bedenini yaz" biçimindedir ve kadın yazarın, erkeğin kendisine yakıştırdığ 1 edilgen tasarımı aşmak gibi bir derdi vardır. Türk öyküsünde böylesi bir sivri çıkış az olmakla birlikte kadının, erkeğin gözüne terk ettiği bedenini bu yıllarda anlatıp anlatamadığ1 önem taşımaktadır. Kaygusuz'un Sandık Lekesi kitabındaki "Kadın Sesleri” adlı öykü, aldatılan eş ve gayrı meşru sevgili olarak iki kadının birbirlerini seslerinden tanıma, konumlandırma, fizyolojiye aktarma, yani tasvir ve analizine dayanır. Bayan B veya Berna; Bayan A, Ay, Ayş veya Ayşe’nin kocasıyla sevgilidir. Bayan B veya Berna, diğerini telefonla arayarak Kadın Dayanışma Derneğinin bir anketi için rahatsız ettiği yalanıyla onu tanımak ister. İsimlerdeki oynama, belirsizlik bu ilgi biçiminin çoğulluğuna gönderme olabilir. Sese ilişkin çıkarsamalar dolayısıyla kadın dilinin açıkça yer aldığı bir öyküdür. Kadınların birbirlerini ses tonları üzerinden tanıma çabasında Ayşe'nin sesini diğeri yorumlar: "Cirtlak sesli, kısa boylu belki, küçük gözlü”, "Ne kaba, e’leri a’lara karıştırarak, / Kabarık kabarık söylüyor" [...] "benden beş yaş küçük, dansözler gibi / Uzundur saçları, rengi perhidrolle / Açıyor olmalı... hıh küçük görünüyormuş, / Eli ayağı kocamandır bunun, dudakları etlidir, / 
Gülerken bir karış boşluk açılır yüzünde", "seni kenar mahalle dilberi seni, / Seni ölçüsüz kadın” (2000: 32-33).

İç konuşmadaki küçümseme açıktır ve rakibesinin güçsüzlüğünü, güzel olmayışını onun sesinden, ifadelerinden çıkarmaya çalışır. "E ve a seslerini karıştırıyor" kınaması, hıh ünlemi, küçük görünüyormuş dudak bükmesi, "seni kenar mahalle dilberi” yakıştırması, kadının tepki ve anlamlandırma çabası uzantısında kendince konuştuğunu gösterir. Beden tanımlamalarına bakıld1ğında canlı bir kadın dili olduğu açıktır. Ayşe'nin gözünden de diğeri küçümsenir, ancak muhatap tercih edilen kadın olduğu için yer yer temkinli çıkarsamalar yapılır: "Herhalde okul bitirmiş, görgülü bir kadın, / Ne yumuşak bir sesi var", "gözleri böcek gibidir, saçları kısacıktır / aynı oğlan çocuğu, cincik boncukla doldurmuştur boynunu", "sesi gittikçe bayatlaşıyor; / Ne tuhaf kadın böyle” (2000: 36). Telefon görüşmesinin sonuna doğru evli kadın her şeyi itiraf edercesine Berna'nın "psikolojik boyutta inceliyoruz meseleyi" lafina, "Senin sikolojini yerim ben" der (2000: 37). Kadın dili açısından Ayşe'nin kullandığ 1 bu cesur ifade, kadının kıskançlık, öfke hâlinde rahatlıkla argoya geçebileceğini gösterir.

İlgili dönemin bir başka öykücüsü Türker'in öncelikle bir söyleşisinden yola çıkarak kadın cinsine dair dil algısına yer vermek uygun olacaktır:

Yazılardan anladığımız kadarıyla feministsiniz değil mi? Feministim. Öykülerimin bir parça erkek dili taşıdığı söylendi. Kadın dili olup olmadığına gelince; neyi nasıl kullandığın önemli. Kullandığın dil bir parça daha fazla şiddet, öfke taşıyorsa buna erkek dili sıfatı yakıştırılıyor. Asla kabul etmiyorum. Benim derdim eksiksiz insanı anlatma çabası. Ben kadınlar ordusunun içinde büyüdüm, anne, abla, teyze... Erkeklere tahammül edemiyordum. (...) Yaşamda merhamet duygusunun çok eksikliğini hissediyorum. Çok paçavra, modası geçmiş, anneannelerimize aitmiş gibi görülüyor. Kesinlikle insan ilişkilerinde merhameti önemsiyorum. Ben merhamet duygusunun çok önemsendiği bir ailede büyüdüm. Başkasının hikâyesi gözetilirdi. Kimseye kötü denmezdi hemen, onun arkasinda olanlar anlatılırdı. (Özcan 2003).

Yazarın, söyleşide ifade ettiği erkeklere karşı olumsuz yaklaşım, öykülerine de yansımıştır. Ağula kitabındaki "Boş Mermer Yazıları” öyküsü, kadının kendi bedenine erkeklerin gözünde canlanan imaları okuyarak bakması açısından iyi bir örnektir. Konu, ölen babasına mezar taşı yazdırmak isteyen genç kadın ve taş yazıcıları arasında geçer. Baba, "Alım, satım, dışalım, dışsatım, taahhüt, inşaat, turizm, organizasyon, (...) Dolanma, dolandırma, evrak, sahte, varaka, nakit, muhasebe, defter, çek, vade, senet...” (2007: 94) sözlerinden anlaş1dığı üzere kaçak bir hayat sürdüğünden kızı mezar taşına ne yazdıracağını düşünür. Kendisi için baba, uzun ve anlamsız bir çocukluktur. Yazıcılar ise ilk 
defa bir kadının bu iş için gelmesini yadırgar. Onların algısına göre, kadın bu konuda dilsizdir. Genç kadın, oradaki sözler ve bakışlardan kaçıp kırmızı bir ayakkabı alarak evine gitme isteği duyar:

İşçiler bomboş geçen hayatların hikâyesini bir cümlede mermere kaz1maktan sıkılmış, bana, topuklu çizmelerime, çizmeyle eteğin buluşmadığı o kısa aralıktan hayal meyal seçilen tenime, saçlarıma, kulaklarıma, kulaklarımdaki mini minnacık ışıltılı küpelerime, çantanın kapağını açıp kapayan uzun tırnaklı zarif ellerime bakıyorlar. (2007: 95)

Kadın, bu ayrıntılarla tanımlanan kendi gövdesine yönelmiş erkek bakışlarındaki merhametsizliği iletirken, aynı zamanda kadının bir gövdeye dönüşen toplumsal haritasını çizmiş olur. Kadın yazarın, erkeğin rahatsız edici bakışlarını dile getirmesi, üstelik kaçma isteğinde faydasız olsa bile kırmızı ayakkabı alan babaya sığınma isteği, varlığını cesur veya işveli bir şekilde öne sürmediğinin itirafıdır. Kaçamayınca babasının taşına isim, tarih ve hatta yazı da yazdırmadan işi halletmek ister; ancak yazıcılar izin vermez. Bunun üzerine genç kadın, ironik bir durumu gösteren şu yazıyı ellerine verir: "Babama / Bir tatlı huzur / Ruhuna El Fatiha / Sacit F. Kafika" (2007: 95). Yazarın röportajında altını çizdiği merhamet eksikliği, öyküde, erkek figürlerin yani baba ve mezar taşı yazıcılarının şefkatten uzak tarafları dolayısıyla ortaya çıkarılır. Beden tanımlamasında kadın yazar, erkeğin dilinden rahatsız olmaktadır. Ancak onların diline teslim olmaz, uzak ve sorumsuz babaya huzuru gönderirken, taş yazıcılara da alayı uygun görür.

İncelenecek bir diğer isim olan Erdoğan, bir söyleşide kendi öykü diline dair yapılmış iki farklı yorumu paylaşır ve kadın dili açısından nerede olduğunu aktarır. Kitabını okuyanlardan birisi onu erkek zannetmiş, Ruth Klüger adında biri ise "[b]ir kadın yazar çıktı ve edebiyatta erkeklerin tekelinde olan özyıkımı, kadın dilinden taviz vermeden anlattı" demiştir (Günçıkan 2011). Kendisi de bu kadın dili tespitini çok beğenmiştir: "Çok, çok övücü bir cümle aslında ve beni şaşırttı, çünkü ben yazarken bir erkek dili benimsediğimi düşünüyor, kendimi bu sebeple eleştiriyordum" (Günçıkan 2011). Erdoğan, negatif bir anlatma ile kadın bedenini Taş Bina ve Diğerleri kitabındaki öykülerin bütününde işler. Farklı milletlere mensup kadınların yer aldığı "Sabah Ziyaretçisi”nde imgesel bir dille kadın bedenine ait tasvir ve benzetmeleri hastalık çevresinde sunar:

Sağımdaki odada, kuzeyin soğuk dilberlerine şarapnel yaralarını göstermekten çok özel bir zevk duyan Bosnalı kalıyor - çoğumuzun yaraları daha sessiz. Solumda ise porno filmlerde çalışarak geçinen bir Rus, sabahlara dek çoktan kapanmış bir dönemi protesto eden şarkılar dinliyor. [...] Ortak sığınağımızda, içki, ter, tütün, kirlenmiş ten kokulu bir bulut sürüne sürüne dolanmakta. (2009: 4) 
Bedenin kısıtlı oluşu daha da önemlisi hastalıklı oluşu cinsiyet tasvirini başka bir yöne taşır. Öyküdeki tasvirler, kadın cinselliğinin fotoğrafından ziyade, toplumsalın hapsettiği yıkımı gösterir. İlgili alıntılar, kadının kendisini, hemcinsini anlatmasında olumsuz çağrışımlar taşımasına rağmen bir şefkat yaklaşımı olarak da değerlendirilebilir. Çünkü gerçekçi bir anlatımla yapılan tasvirler acındırmaya yakın bir beden aktarımıdır. Örneğin şarapnel yaralarını göstermekten zevk almak, porno filmlerde oynamak ve eski sosyalist dönemi eleştirmek; savaşa maruz kalan ve ekonomik sistemle y1kılan insan bedenini anlatmaktır. Anlatım, acındırmaya yakın bir beden teşhiri olsa da yazar, tersini dikkate sunar. Hatta ter ve tütün kokusu doğallıkla erkekle özdeşleşir. Çünkü öyküdeki kadınlar, hastalıklı varlıkları ve güzellik histerileri arasında sıkışmışlardır. Bu sıkışmanın kitapta özellikle vurgulandığ 1 izlenir. Bunlardan biri "Tahta Kuşlar" öyküsüdür. Kadın bedeni, kendine ait olanı var etmek, kendini tam olarak görmek ve göstermek üzerinden bu öyküde hizalanır. Öyküdeki kadınlar kaldıkları sanatoryumda "Almanların hepsi veremli, biz üçüncü dünyalılar ise astımlıyı" açılaması ile tanıtılır (2009: 19). Bu hasta kadınlar kendilerine Amazon Ekspresi adını takarlar: “'Amazon Ekspresi' Yağmur ormanlarını mı kastediyorlardı, yoksa erkekleri, sağ memeleri gibi kesip yaşamlarından atan, av ve savaş ustası efsanevi kadınları mı?" (2009: 21). Bu, beden ve dil konusunda bir düğüm sayılabilir. Benzetme, özgürlük ve cinsellik anlamında hastalıklı bünyenin karşı çıkma tavrı olarak belli bir anlam taşır. Kendilerine bu adı vermeleri ve sonunda bedenlerini sağlıklı erkeklere gösterebilme şehvetleri ve hemen akabinde baş başa kaldıkları suskunluk, Amazonların da sonuna kadar özgür olamayacaklarını, karşıt bedene duydukları isteği yansıtır.

Yazarın "Mahpus" başlıklı öyküsü de yine yıkılmış bir kadın bedeninin tasviridir. Erkeğe dönüşen beden, kadınsılığını unutmuştur. Anlatılan, hamile bir genç kadının taş binaya sabahın ilk saatlerinde gidişinin psikolojik öyküsüdür. Vücuduyla hesaplaşan, yaşı biraz geçmiş bu kadın, kendisini gizlemeye gerek duymadan anlatırken yıpranan hayatını dile getirmiş olur. Bunu tersten söylerken de varlığını iyice belirginleştirir: "Kuklayı şöyle bir sars, tozlarından silkele, ayna karşısına sürükle. Yüzünü gözyaşı izlerinden arındır, gündelik katılık maskesini tak ki, insan içine çıkmaya hazır olsun" (2009: 38). Kadını, gazeteleri okurken dayatılmış kadın imajı ve kendi duyarlılığı arasında daha belirgin görürüz:

Sadece kadınlar gözüne batıyordu. Şık, alımlı, sonsuz bir gençlik-güzellik hastalığına yakalanmış gibi duran, objektife sonsuzluğa bakarcasına bakan kadınlar. Güzel olmayan hiçbir şeyi yiyip içmez, giymez, söylemezlerdi. Aptalca kaybedilmemiş, trajedi-geçirmez bir hayatın belirgin rahatlığ içinde, insan ilişkileri üzerine fikir yürütürlerdi. (2009: 41) 
$\mathrm{Bu}$ satırlar, bedeni aşan bir kadın zihniyetini var etmek isterken, yalnız kalış da bir başka trajedi olur. Kadına ait süsleri küçümseme, dekoratif kadın varlığı veya hayallere saklanamama aslında toplumsal bir cezadır. Örneğin, oturduğu kahvenin garsonu onu ciddiye almaz. Kadının kısalmış eski eteği ve bacakları değil; sadece açık bir yara gibi rujla çizilmiş dudakları gözüne çarpar. Erdoğan'da, kadın özne bedenin tahribi altında cinsiyetsizmiş gibi davranmak ister; ancak aynalar ve insanlar onun gizlediği tarafa bakarak karanlığı görürler. Bir kadın yazarın bu tavırla kadın bedenini anlatışındaki protest eğilimi tespit ederken, bunun yanı sıra kadının süslerinden açıkça vazgeçişi dile getirmesinin de altını çizmek gerekir.

Aramızda adlı öykü kitabıyla incelemeye dâhil edilecek Karatepe'nin dil, öykü ve kadın meselesindeki görüşleri ise şu şekildedir: "Kadın yazar ya da kadın öykücü tanımlamasının gerekçelerine bakıyorum önce... Eğer bu tanım feminizm şartlandırmasıyla bir cinsiyet ayrımına çıkmıyor bilakis kadın ve erkeğin farklarını öne alıyorsa sorun yok" (Öz 2009).

Karatepe, kadın dilini kendi dünyasında büyümüş bir dil olarak işler. Büyümüş olandan kast edilen, anlatıcının kadına ve çocuğa masumiyet, fedakârlık misyonu ile yaklaşırken değişen dünya ve şartları dikkate almasıdır. Onun öykücülüğünde kadın bedeni, iki kadının aynı erkek için giriştiği iç çatışma üzerine kurulu "Aramızda" adlı öyküde daha açık görülmektedir. Yıllar öncesinde kalmış bir ilginin, bir düğün salonunda zorlu karşılaşmasını konu edinen öykü, gerek anlatımın genç kadın üzerinden yapılması, gerek iç konuşmalardaki doğallıkla sözü edilen büyümeyi gösterir. Anlatıcı kadın, adamın karısı ile aynı koltuk hizasında otururken, kendini onunla dolaylı olarak mukayese eder: "Çocuklar tuvalete gidince karısı beş kişilik yer ayırmı̧mı̧̧. [...] İki yeşil gözlü, kumral kadın yan yana oturuyoruz. O da oturuyor. Evli misiniz, diyor karısı. Gözlerinden gözlerime iki yılan yürüyor. Hayır, diyorum. Canım acıyor. Kısmet, diyor” (2012: 7-8). Normal, akışkan, hayata dair, gündelik dilin iki kadın arasında ironiye ve gizli bir saldırı hâline dönüşmesi kadına ait dili ortaya çıkarmaktadır. Evlenmemiş olması dışında kendisine benzeyen kadının bakışında görülen yılan ve canını acıtan kısmetsizlik iması ve öncesinde yer alan "mış" $l_{1}$ ifadelerdeki öfkeyi birlikte düşünürsek, iki tarafın da dengede duran bir tepki içinde olduğu anlaşılır. Anlatıcı kadın kendi görünüşünü ve tercih edilen karşıdaki kadının bedenini tanımlar:

Eşarbımı pırıltılı bir şalla süslemişim, ayakkabılarımı çantama uydurmuşum. Hepsi bu. Tepeden tırnağa süzüyor beni önce karısı. Bana yarım ağız merhaba demesinden belliydi. Biliyor, olup biteni... Seçilen kadın olmanın gururu ışıldıyor gözlerinde. Kadınlığı, doğurganlğ̆ı, gelip oturuyor aramıza. Konuşurken elini çenesine dokunduruyor kocasının, omuzlarındaki tozları süpürüyor. (2012: 9) 
Geri çekilmiş, marazi kadın dilinin kayboluşu, yerine muhafazakâr diye tanımlansa bile kimlik olarak kendini modernliğin içinde bulmuş söylemini, oradan kuran kadın imajı, ağlamak yerine gerçekle yüz yüze gelmekten çekinmemektedir. Buna göre kazanan kadın yıllar öncesindeki ilişkiyi bilip oradan kendi cinsine olan nefretini de açığa vurur. Beden çocukla konuşur, anlatıcı kadında ise kaybetmenin detayları vardır.

Seyyid Kutub, Mevdudi gibi Türkiye'deki İslami düşüncenin kaynak isimlerini okuyan anlatıcı kadın "kendisine benzemeyen" olarak tanımlayabileceği bir başka kadının bedenini gözlemlerken, kendi duygu ve değer dünyasını da belirtmiş olur: "Saçları koyun postu gibi kabarık bir kadın önümüzdeki sıraya geçmeye uğraşıyordu. Kadın geldi tam çocuğun önündeki koltuğa oturdu. Havaların serinlemesine rağmen bluzünün omuzları açık, eteği mini, yırtmac1 da oldukça derindi” (2012: 8). Burada kadının kendi pırıltılı şalı ile eleştirdiği süslü kadının dekolte giysisi arasında, görünürlük arzusu bakımından farklı olsa da bir benzerlik vardır.

Karşı cinsin bedeni, incelenen kitaplarda neredeyse anlatılmaz. Sakatlık ve mizahi yön gibi kısmen değinmeler vardır. Karşı bedeni cesurca anlatan $\mathrm{Ha}$ tice Meryem'dir. Kitabının içeriği de zaten kocaların davranışları ve kadınların tepkileri olarak tanımlanabilir. Yazar, bunun neden şimdilerde yazılabildiğini dolaylı olarak ifade eder. Kadınlardan dinlediği hikâyeler, onun diliyle "hikâyenin özgürleştirici sesi", "dinleyiciler arasındaki bir nesil sonrası kadınlarını özgürleştirmiş, onların kafasında otoritenin gücünü kırmış, en azından ehemmiyetini zedelemiştir” (2013: 79). Kendinden önceki kuşağa borcunu dile getiren Meryem, Sinek Kadar Kocam Olsun Başımda Bulunsun öykü kitabında bu özgürleştirici alan üzerinden erkek bedenini bolca örnekle tasvir eder. Çocuğu olmayan marangoz ve budak benzetmesi; kasabın et, kemik, ilik kokan bedeni; genç bir adamın yılana benzeyen pırıl pırıl derisi, çatallı dili gibi tasvirler; eve döndüğü kapıyı tekmelemesinden belli olan, sofrada çorba sıcak diye tası duvarlara firlatan, ter kokuyorsun denildiğinde söyleyenin burnunu koltukaltına bastıran kocalar gibi tahliller, erkek bedenine gerçekçi ve bir o kadar da ironik bakışlardır. Bu öykülerde Meryem, erkeğin kirli veya özenilir taraflarını mizahî bir biçimde yazar.

\section{Cinsellik}

Kadın öykücülerin dile getirdikleri cinsellik ve erotizm, erkek yazarlarda rastlanan oranda değildir. Onlar imalar ve göndermelerle konuyu ele almışlardır. Hatta onların böylesi bir durum yokmuş gibi yazması da alışkanlıktır. Ancak 2000’li yıllarda, önceki dönemlerden gelen denemeler ve sosyal gelişmeler vasıtasıyla bu konuda belli bir dil, sahne, imaj kurma yoluna gidilmiştir. Bu 
başlık altında ele alınacak ilk öykü Kaygusuz'un "Aşkâr" ${ }_{1}$ dır. Ergen yaştaki bir kızın uğradığı cinsel taciz ve bunu yapanın ölüm haberi, öyküde ana olaydır. Canan banyodayken, ona yıkanmasında biraz hoyratça yardım eden annesi, ölen kişi hakkında, kızına konuşmama tembihinde bulunur. Onun yıkanmas1, su ve beden ilgisi kirin atılmasından da öte kızın bedenindeki bu gizli ve asla söylenmeyecek tacizi, annenin kendi elleriyle kazıması anlamına gelmektedir. Kızın kalçasına kadar uzanan siyah saçlarının aşkâr denilen küllü su ile yıkandığı sahne, anne ve kız arasındaki konuşmayı, iç monologları, kadın ve cinselliği başarıyla yansıtır. Canan'ın uğradığı haksızlığın bedenindeki izlerine su değdikçe acıması, kadının sesiyle ve vücuduyla anlatıcı tarafından ergenlik ve cinsellik boyutlarıyla verilir. Psikanalitik çatışmayı yansıtan annenin çökmüş bedenine karşın kızının körpe bedenini haşlarcasına yıkadığ1 kısım, bakışlar, tembihler, sıcak su gibi ögeler anne ve kız arasındaki gizli dilin dolayısıyla kadın dilinin detaylarıdır. Annenin merhamete azıcık yaklaştığı yerde Canan'ın “Gülsüm’ün siyah kuyusuna yeniden girmek istedi” (2000: 65) cümlesi ile öykü yine psikanalitik düğüme uzanır. Kızın saçlarını kesmeden önceki sahne ise finaldeki büyüme ve değişim zorluğuna hazırlanışın alt yapısını kurar: "Gülsüm, aşkârlı suyu Canan'ın uzun upuzun saçlarına yedire yedire, damla damla, ovuştura ovuştura döktü. Günlerdir ilk kez kızına okşarcasına dokundu. Canan'ın gece karası saçları, Gülsüm'ün canlı parmaklarının arasında, kırmızı bir ışılkla esneyerek uyandı"(2000: 66). Canan'ın uzun, güzel saçları kesilince üzerindeki gözler uzaklaşmış olacaktır. Bu öyküde, kadın ve cinsellik ilgisinde yazarın imgesel dili yakaladığını ve onu en mahrem yerde anlatabildiğini tespit etmekteyiz.

Hatice Meryem, kadının iç gerçekliğini ürkmeden yazdığı Sinek Kadar Kocam Olsun Başımda Bulunsun isimli kitabında cinselliğe neredeyse her öyküsünde değinir. Kadının hemcinsi ile rahat söyleştiği, mecaz ve metaforlarla belirginleşir. Örneğin, cücenin karısı, kocasını anlatırken onun toplum tarafindan horlanan bedenine nasıl sahip çıktı̆̆ını cesurca söyler:

Cüce kocamla akşam vakitlerinde başbaşa kaldığımızda varımız yoğumuz olan bu çok güçlü duygunun tesiriyle zamk gibi yapışırdık birbirimize. Sağlıklı bir pire gibi ak ve kara, iri ve ufak, yumuşak ve kaba nice yerlerime süründükten sonra, dünyanın o en saklı ve aynı zamanda en görünür yeri olan o depderin, o yaşam dolu, o kimsenin bizi bulmayacağ 1 muhteşem deliğe girerdi bütün bedeniyle. (2002:14)

Tüccarın karısı, kocasını bir seks bağımlısı olarak tanımlar ve neden bir tüccarla evlendiğini de şöyle açılar: "Elbet bir gün beni benden kırk yaş küçük bir kızla aldatacağı gün geldiğinde, şu yeryüzünde sevgisizliğin yerini doldurabilecek tek şey olan param olsun diye" (2002: 54). Sünepe, obur, şopar bir adama razı olan veya yakışıklı, emekli, şair karısı olan kadınlar, cinselliklerini 
bazen şaşırtıcı, bazen düz bir anlatımla eksik veya fazla anlatırlar. Anlatıcı da kendileri olduğu için daha içten bir dil ortaya çıkar. Burada erotizm cüce kısmında görüldüğü üzere sınırları zorlar ve diğerlerinde de kadınsı tahayyüllere açıkça yer verir.

Türker, "Suskun Bir Çocuk"ta anlatıcının yazma eylemine değindikten sonra yazının cinsiyetsizliğine ciddi bir biçimde vurgu yapar. Böylelikle kadın yazar kimliği ve yazı üzerine düşüncelerini iletip öyküyü kurar.

Bir yazar, kimilerinin diliyle bir kadın yazar olarak büsbütün aptal, büsbütün suskun, büsbütün durgun çocuk Feryal'i, çocukluğumun Feryal'ini nasıl anlatmalıyım sizlere? Göğüslerimin ve cinsel organımın yazımla hiçbir ilgisi ve ona bir hayrı yok, yok olmasına ya, benden bugün beklenen ve kimilerinin fotoğraflarımda ve yazdıklarımda bulduğu, bulduğuna sevindiği, yaşamın altın oranına denk getirerek içini ferahlattığı güzellik ve aklı hırpalamadan, örselemeden, üstelik olabildiğince dürüst kalmaya çalışarak bunu nasıl yapmalıyım? (2007: 16)

Türker, kadın yazar ve cinsiyet üzerindeki algıya önemli bir eleştiri getirirken anlatmak ve kendini çeşitli beklentilere bağlı sunmak arasındaki açmazı söyler. Böylelikle anlatmanın cinselliği aşması, kadından beklenenin sınırlarına bir çocuk dolayısıyla nasıl yaklaşabileceği gibi sorunları üst üste koymuş olur.

Erdoğan'ın yukarıda anılan “Tahta Kuşlar”ında, H. Üniversitesi kürek tak1mından dört gencin botlarıyla irmaktan her geçişlerinde, onlara vücutlarını sergilemek isteyen hasta bünyeli kadınların acıklı cinselliği söz konusudur. Bunlardan biri olan Filiz taşların arasından inerken şöyle analiz edilir: "Tehlike onu uyarmış, bütün duyumlarını kamçlamıştı. Cinsel arzuya benzeyen bir duyguyla doluydu" (2009: 28). Kadınlar, kısa bir süreliğine de olsa mutlu olur ama ardından külçe gibi bir pişmanlık onları sarıp sarmalar. Eksik beden ve cinsellik, hayata tutunamamak olarak sahneye çıkar.

Karatepe, "İstihâre" öyküsünde bir kız çocuğunun ağzından ailesinin dramını anlatırken kadın ve cinsellik diline ilişkin mizahî bir üslûp kullanır. Öyküde, okul müdürü olan baba, haksız bir biçimde bir hafta açığa alınır ve aile bunun üzerine başka bir yere taşınma kararı alır. Küçük kıza, olacakları rüyasında daha iyi anlayabileceği inancıyla istihareye yatması öğretilir. $O$ da rüyasında pijama giymiş Zeki Müren’i ve evin önüne gelen beyaz minibüsü görür. Minibüs şoförü, aslında bakkal Emine Abla'nın hoşlandığı kişidir.

Emine abla, elbisemin göğüs hizasında ufak ufak kabaran ve varlığı beni çok rahatsız eden çıkıntıları süzdü. Sırtımı biraz daha kamburlaştırarak annemin arkasına doğru geçtim.

Küp devrilmedi yani, dedi...

Gülüştüler.

Ne küpü yaa... dedim içimden. Küp müp yok bizde? (2012: 57) 
Burada küçük bir kızın gözünden aşk ve beden anlatımı işlenmiştir. Örneğin, kendisine takılan Emine Abla şöyle anlatılır: "Bakkal Emine abla masaya dizini dayamış iki iri balona benzeyen göğüslerini yukarıya almış, uzaklara dalmıştı. (...) Genç adam mazot kokuyor, Emine ablanın gözlerinde binlerce çiçek açıyordu" (2012: 61). Emine ablanın sevdiği kişiye karşı heyecanını fark eden kız, küp devrilmesini de bununla birleştirir. Kadın yazarın diliyle, üstelik muhafazakâr bir söylem içinde, cinselliğin ergen bir kızın gözünden iletilmesi, hayatın olağan ve abartısız bir cinsellik içerdiği şeklinde değerlendirilebilir. Burada geçen cinsellik iması, "Loş” öyküsünde kına gecesi olan kızın hayata karışan bir dürtü ile konuşması şeklinde gelişir. Kız, "Aşrı aşr1 memlekete kız vermesinler" türküsüne içinden "versinler anam versinler... evimizi ocağımızı kursunlar, babamızın başını bekleyecek değiliz a!”(2012: 18) diye cevap verirken büyümenin doğallığıyla konuşmuş olur.

\section{Merhamet}

Bu başlık altında, alışılmış bir üslûbun benimsendiği dil ele alınacaktır. Çünkü bir kadın yazarı, erkek yazardan ayıran alış1mış dil ve üslûp burada açıklanabilir. Yukarıda alıntılanan kadın yazarın duygusal dil tercihi, merhamet ekseninde daha kolay tanımlanabilir. Ayrıca bu duygusallık melodramatik ve şefkatli dil olarak da ayrıştırılabilir. Melodramatik dil, Servet-i Fünûn sanatkârlarının hassasiyet yüklü dil mirasıdır. Bu tarz, ünlemli sesler ve gerçekten kaçış anlatımları olarak düşünüldüğünde, romantik edebiyatın kadın romancıları tarafından sürdürülmüştür (Ercilasun 1997: 441). Onlar, bu bol ünlemli ve bireyin romantik, incelikli tarafını aktaran dili, kendi kadınsı durumlarını yansıtmak için kullanmışlardır. Melodram, toplumsal gerçekçi bir anlayışla karşılaşınca, bu dilde bireysel acıların yanı sıra sefalet de yer alır. 1970 sonrası öyküde Füruzan, Sevinç Çokum, Gülten Dayığlu gibi yazarlar, bu anlatım tarzını örneklemiştir.

İncelenen dönemde ise Mukadder Gemici'nin öyküleri bu paralelde düşünülebilir. Onun kadın duyarlılığı ve dram içeren bir öykü dünyası kurduğu söylenebilir. Taşranın ve insanlarının dramlarını öyküye taşırken böylesi bir dilin uygun olup olmadığı da tartışılabilir. Ancak anlatıcının olaylar karşısında hep kurban edilmiş kişileri, acılı hayatları konu edinmesi melodramı çağrıştırır. Gemici'nin bir olaya dayanan öykülerinde taşra ile merkez arasına sıkı̧̧ı̧ insanların dramları vardır. Örneğin "Asla Pes Etme" adlı öykü, yetiştirme yurdunda büyümüş ve öğretmen olmuş yirmi beş yaşındaki Hayat Hepgülsün’ün yaşadıklarını anlatır. Öykü Hayat'ın, kızı ölünce yaşama küsmüş Nermin Hanım'la paylaşımları üzerinedir. Alı̧̧ılmış, açıklamalarla dolu bir dil kullanılmışır: "Hali vakti yerinde, kalabalık bir evde büyümüştü. Radyo imtihanlarını kazanmışı. Kendisi gibi radyo sanatçısı olan Erol'la evlenmişti” (2011: 26). 
Öyküde Hayat, kadının inceliğini ve merhametliliğini okura iletir. Kulland1ğ1 dil, sürprizi olmayan, metafor düzeyi belli seviyede kalan bir dildir: "[B] ir film seyretmişsindir, canın yanmıştır, arkadaşın üzmüştür, ağlarsın, derdin vardır, hava sıcaktır, hava soğuktur, güneş açmıştır, kar yağmıştır, bir sıcaklık ararsın, bir dokunuş ama yoktur. Aynı şeye aynı senin gibi şiddetle ihtiyacı olan diğer çocuklar vardır sadece" (2011: 29). Yazar, kadını zayıf ve geçmişe gömülü bir tip olarak anlatır. "Bazıları hani derler ya, 1-0 önde başlar hayata. Benim gibilerse -1 hatta -2'den başlar” (2011: 35).

Türker'in "Hayat-Memet Meselesi” öyküsü, melodram diline bir örnek oluşturur. Kırsalda yaşayan ve kolunda, ayağında protezi olan Memet' in ilk gençliği ve aşk1, duygusal tonu yoğun bir dille işlenir. Ancak yer yer Memet'in ağzından böylesi imgesel bir dile geçilmesi gerçekliği zorlar:

Bayırbağ’a sürüklense. Yok yok balık olsa, suda değil havada boğulsa. Yayın olsa baygın bakışli, yorgun yüzgeçli yayın. Su köpür köpür, cıvıl cıvil. Bir ömür onu taşıyacak, götürecek, götürecek. Belveren’in çam ormanının içine. Çoktan ölmüş çocukluğunun Usulcalı Deresi'nde suya don çözmüş, sonra da balık olup balık kalmış Memet'i gibi arkadaşlarını korkutup da, 'Memmeett!' diye bağırtırken gitse. Gidecek yer kalmayana kadar. (2007: 30)

$\mathrm{Bu}$ öykülerde insanın iç dünyasına seslenen bir anlatım göze çarpar. Anlatıcının, okurun duygu hâlini acımaya doğru götüren bir üslûp takındığı bellidir. Kadın anlatıcının, hayatın zorluğu karşısında olup biteni, duygu yükünü ihmal etmeden ancak abartmadan anlatması, şefkat ve merhamet başliğı altında irdelenebilir. Bu kapsamda şu öykülere yer verilebilir:

Kaygusuz, “Ortadan Yarısından” öyküsünde İzmir, Bornova'da yoksul bir semtte, hasta bir adamın karısı Gülümser Hanım Teyze'yi, yoksulluk ve hastalığın amansızlı̆g içerisinde konuşturur. Kocasının yemek konusundaki titizliğine karşı kendisinin gösterdiği hassasiyeti şöyle paylaşır: "Söylenmesin diye iyice pişirdiydim ateşte. Getirdim sofraya, ortadan ayırdım koydum önüne, yarısını ben yedim yarısını o. Hatta Ömer Efendi hepsini bitiremedi bile... Ondan sonra başladı kıvranmaya!" (2000: 10). Kadının çaresizliğini ifadesi, merhamet hislerini kabartan bir melodram olmayip, katlanmak zorunda olduğu hayatın yalın anlatımıdır.

Türker, fantastik ögeler taşıyan "Kuş Biçimi”nde, kadının başka bir dil arayış zorunluluğunu aktarır. Peri adında bir kadın içindeki "yumru, dert" dolayisıyla adını koyamadığı bir çıkmazdadır. Kadın önce tıptan yardım alır, onu bademcik sanıp alırlar. Sonra "kafuru kokan hoca", kendisine cinlerin dadandığını iddia ederek her şeye kuş motifi işlemesini salık verir. Nihayet o da kuş olup kendisini camdan atar. Kadın, kendisine şu soruyu yöneltir: "Sözcüklerim pek az, ondan mıdır ki?” (2007: 86). Kadın, hocanın tavsiyesi üzerine 
don, gömlek, kravat, sutyen, paça ne bulduysa hepsine daha önce tek olarak işlediği kuş kanatlarını çift hâline getirir ve hafifler:

Ferahlamak ama nasıl, bunca yıl yuttuğu sözler, tam söyleyecekken yutup sindirdiği, ağzının içinde top top toparlanmış sözler. Sırtında, yüreğinde, nefesinde, karnında bir kubbecik bile yok, dümdüz oldu gitti.

Bakmış anlatıyor, anlatıyor o da. Demek diyecekleri varmış. İpliklerle, olsun. Söylenir onlarla da. (2007: 86)

$\mathrm{Bu}$ ifadelerde merhamet duygusu yansımaktadır. Daha da önemlisi öykü, konuşamama istırabının, kadında yarattığı bunaltıyı imgesel bir şekilde aktarmaktadır.

Bir başka örnek olarak, Karatepe'nin "Dönemeç” öyküsündeki ergen kız verilebilir. Öyküde, sınava girmek için hazırlanan ancak ailesinin olumsuz yaklaşımı nedeniyle sınav salonuna gönülsüzce giden kız kendisine acır. İnsanı, merhametle, anlayışla karşılamayan sistem, onun da karşısındadır. Üstelik dram bununla da bitmez. Başörtüsünü sınava girerken "suç aletini saklar gibi” saklamak zorundadır. Sınavdan çıkınca aşamayacağı çok şey olduğunu düşünür: "Bir dönemeci savrularak döndüğünü ancak şimdi akil baliğ olduğunu ve onu sonsuza dek kaybettiğini... Bağıra bağıra ağlıyordu” (2012: 84). Teselliler onu durduramaz. Her şeyi baskı altında tercih etmek ve bilmediği bir gücün karşısında inandıklarını saklamak, ona bir dönemece geldiğini ve bunu aşamayacağını düşündürür.

Gemici’nin “Kızdan Başka” öyküsü, Türk kültüründeki erkek çocuk isteğine kadın diliyle bir değinmedir. Kızların okutulması ve annenin böylelikle kurtuluşa ereceği zannı üzerine başarılı bir öyküdür. İlk kız Fatma’nın ağzından anlatılır öykü. Yine duygusal ve merhamete dayalı üslûp açıktır. "Babam annemi çok sever, annem de onu. (...) Beş doğum yapıyor annem, beşi de kız. İkisi ölüyor. Bu da annemin tek kusuru, yani kız doğurmak” (2011: 126). Anne ölüm döşeğindeyken kocasından kızları okutma sözü alır. Aynı yazarın "Yapmasaydın" öyküsünde, baba ölünce dört kız ve anne kalakalır. Büyük kız çalışır ve diğerlerine bakar. Hepsi evlenir, o hâlâ bekârdır. "Kızların düğün fotoğrafları poz poz, yeğenlerin okuma bayramları, müsamereleri, doğum günleri... Hepsi evin her yanına yayılmış. Annemin âdetiydi:" (2011: 142). Mehtap için sonrası uzun bir pişmanlıktır. Kız kardeşleri "yapmasaydın” derler. Kendisine evlenme teklif eden Harun, İzmir'e yerleşmiş ve üç çocuk sahibi olmuştur.

Görüldügü üzere, Gemici ve Türker'den başka Kaygusuz'da da bu tarz bir fedakârlık görülmektedir. Kadın dili geleneğinin eskiden beri bir merhamet ve şefkat yaklaşımı taşıdığı tespitine, günümüzde de sürmekte olduğu eklenebilir. 


\section{Çocukluk}

Kadın öykücülerin kendilerini ifade etmeleri çocuk teması üzerinden daha çok gerçekleşmiştir. Sözlü ve yazılı anlatılarda çocuğa odaklanan kadın, Cumhuriyet dönemi Türk öyküsünde çoğunlukla çocuğun mutsuzluğu ve duygusallığını ele almaktadır. İlerleyen dönemde ergen diline de yer vermiştir. Çocuk masum bir ifade aracı olarak kaçma ve sı̆̆ınmayla, ergenlikse daha çok çaresizlikle ilişkilendirilmiştir. İncelenen öykülerdeki ironi, masumiyetin yerine geçer ve özgürlüğü getirir.

Türker'in, “Suskun Bir Çocuk”u ezilmiş kadın ve çocuk imajından yola çıkar, ancak söz edilen masumiyet, acıklı durumdan özgürleşme ve bireyleşmeye doğru ilerler. Öykünün konusu, çocuk ve annenin, ölmüş babanın zengin amcasını ziyarette yaşadıklarıdır. Amca yaşlı ve hasta, karısı cicianne duygusuz ve sonradan görmedir. Bu akraba eleştirisine dayalı anne ve çocuk kurgusu, Füruzan'da ("Taşralı", "Haraç”), Tomris Uyar'da ("Çiçek Dirilticileri”, "Sarmaşık Gülleri”) işlenmişti. Kız çocuğundaki verili dil devam ederken, masumiyetin yerine sorgulama devreye girer: " 'Onun babası yokmuş, diye söylenirdi ciciannenin cici torunu. İyi kalpli kızlar, 'Yaaa, ne kötü', diye içlenirlerdi. 'Niye yok?' 'Ölmüş', diye cevaplardı bizi tanımayan Ebru. O zaman babama da kızardım. Bütün bu saçma soruları yanıtlamak zorunda olan budala, çelimsiz, kara kuru kızı bırakıp gitti, diye" (2007: 20).

Ancak burada içine kapanan değil, kızan bir çocuk figürü ortaya çıkar ve dile mizah katarak yaşanan dönemin değişmiş algısını yansıtır. Kadın öykücü, bütünüyle melodrama yenilmek istemez. Feryal, duruma üzülse de kabullenmek zorundadır ve şımarık kızı, "yaşliları çok sever, öpersen onlar ölünce sık sık yanına gelirmiş" diye kandırır. Böylelikle onu, dede ve ninesinden korkutmuş olur.

Karatepe, "Bandırma Vapuru” adlı öyküsünde, Türkiye'nin 28 Şubat günlerini çocuk ve siyaset zıtlığ içerisinde ironik bir fotoğraf olarak sunar. Öyküde, İmam-Hatip Lisesi öğrencisi kızın "Bandırma Vapuru” resmiyle birincilik kazanması ve aldığı ödülün ironik yansıması anlatılır. Gözlemler iç monoloğa dönüşür; bu sayede anlatıcı onunla iç içe geçer. Kızın istediği kırmızı bir çorapken paketten bordo kravat çıkması, ödülü hazırlayanlar kadar günün de eleştirisidir. Hiç kimse yapılan işi ciddiye almamaktadır. Ayrıca yarışmayı bir kız öğrencinin kazanamayacağının düşünülmesi de eleştirinin başka bir boyutudur. Küçük kız da durumu iyice anlayınca içinden konuşur:

Çorabı iyiden iyiye kaymış paçalı donu tümüyle ortaya çıkmış, etek hizasından en az iki üç parmak aşağıda görünüyordu.

Görünürse görünsün be, dedi içinden, burnunu çekerek... Resmi yaptık, kafayı açtık, bayrama da gittik ama uzun kırmızı bir çorap çıksaydı ne güzel olurdu şu paketten, bordo bir kravat çıkacağına... (2012: 28) 
Yazarın bu ideoloji ve inanç çatı̧̧masını küçük kız üzerinden vermesi, bir anlamda masumiyetin büyük olaya verdiği sade cevaptır. Kadın öykücü, kız çocuklarını artık şehirleşmiş biçimde ve doğal tepkileri ile anlatmaktadır.

\section{Protest Dil}

Kadın öykücülerin, içerik ve söylenişte alaycı bir karşı çıkma diye tanımlanabilecek protest dile yönelişlerine değinmekte yarar var. Türker'in yukar1da alıntılanan kadın yazarı kafasında canlandıran okura isyanı, Karatepe'nin genç kızları konuştururken sisteme ve ebeveyne kızan dili bunun gelişimidir. Hatta kadın cinsine zaman zaman olumsuz gözle bakan Erdoğan'ın söylemi de bu protestoyu barındırır. Ancak onların öykülerinde alay ve öfke, parçalı bir biçimde yer alır ve bütün atmosfer protestoya bağlanmaz. Birgül Oğuz'un dile aşırı imgeler yüklediği Hah kitabındaki bütünlüklü öykülerdeki dil çeşitliliğinin protest tarafı belirgindir. Türkiye'deki siyasal ve sosyolojik dönüşümler etrafinda anlatılan ölüm teması ve kız çocuğu, alaya yaslanan bir anlatımla öne çıkarılır. Öykü, babanın ölümü üzerine bir kızın ağzından uzun ve dokunaklı bir ağıt olarak da tanımlanabilir. Bu süreçte, çocuğun veya ergenin varlığını idrak ve ifade edişine tanık olunur. Anlatıcı olan kız, babasının ölümündeki ağlayıcı kadınlar korosuna gösterdiği tepki dolayısıyla tanınır: "Esirgemeyen, bağışlamayan anama hep şükürler olsun. Onlar mı? Hah! Onların hali harap. Dünya hafif, insan eti ağır, diyorlar. İnsanın canı ezelden beri toprakla tıkalı, diyorlar. (...) Demiyorlar da kıhlıyorlar: Dört bir ucundan tutuşasın dünya, kalmayasın bana bize onlara dünyaah..." (2012: 15).

Dil oyunlarına açık "hah, dünyaah, ah" tekrarları kitabın protest dilinin de leitmotividir. Toplumun sürekli "ah, vah” ünlemleriyle karşılaşan kızın gösterdiği protesto "hah" ünlemidir. "Sonunda beklenen oldu" ve de "sizin layığınız buydu" anlamlarıyla "hah" alaycı bir tepkidir. Kurguda, anlatıcı kız doğumundan babayla birlikte dünyayı tanımasına, sosyal hayatın içinden erkeğin hizasına zorlandığ1 sürece doğru izlenir. Babanın ölümüyle birlikte büyümeye hızlıca geçilir: "Koridorun öbür ucundaki büyük odaya yürürken yerinden edilmiş bir kavme benziyorduk" (2012: 20). Babayla kuşatılmış bir hayat algisı, kıza aşılanan devrimcilik fikri konuşmasını çevreleyen siyasal arka plan olurken, 1980 ihtilali ve sonrasındaki apolitik söylem de protest dilden nasibini alır: "Üretim esastır! Üretim esastır! Her vakit, yatsı dahil, üretim esastır! Öyle iyi anladım ki hem, avuçladığım gibi şeftali çekirdeğini sokağa firladım, açtım kollarımı iki yana, daldım akşamsefalarının arasına, dizim dirseğim kabuk kabuk yara, kalin! Dedim, bir başıma, kakalin kakalin kamaya!” (2012: 28). Çocuk aklının üretimle buluşması sevimli bir mizah ise kakalin'in bir başına ironiyle söylenmesi protestodur. 
Kitabın dilindeki sürekli sayıklayan ifadeler ve bilinç akışının ironisine inen anlatımlar bu protest dili besler. Kültürel algılara dayanan, önceki metinleri iktibas eden çeşitlilik ise zamanın hızlı ritmini gösterir. Hatta burada da kalmaz ve teknolojinin hız göstergelerine uyarak internet yazışma dilini edebi dile ekler: "bazı yumruklar atıldı ve tmzleyceğz hepniz ded bkışlar kanl kinl tabancalı br adm v dört ucndan tutştu kalbalık ki k ki o ne tutşma ve hvda 1slak br duman çiğ sarı olarktan yutt Memo'yla Metin Amca'yı (...)” (2012: 46). Ancak bu anlatım, sözlerin hıncahınç bir kalabalık ve şiddet ortamında tam söylenemeyeceğini ima ederek sadece hız göstergeleriyle sınırlandırılamaz. Oğuz'da, siyasal ve sosyal protest olduğu kadar ironik bir ilence dönüşen dil, eski ağıtçı kadın geleneğinin ve suskun, ezilmiş kız çocuğunun günümüzdeki değişim ve dönüşümünü gösterir.

\section{Anlatıci Tercihleri ve Dil}

Bu makaleye esas olan yedi öykücünün anlatıcı tercihleri dikkate alındığında, kadın dil ve üslûbu veya dünyaya, insana bakışı bir gösterge olarak görülebilir. Bu tercih elbette tek başına belirleyici değildir. İlgili öyküler anlatıcı pozisyonu açısından kadın, ergen, genç kadın, çocuk, erkek alt başlıklarına indirgendiğinde çıkan sonuç şöyledir: Kitabının bütününde sadece kadın anlatıcıyı tercih edenler, Erdoğan ve Meryem'dir. Ancak bütün anlatıcıları kadın olan Meryem'i, bu tasnife dâhil etmek sonucu etkileyecektir. Bu nedenle, onu tek kadın anlatıcı olarak değerlendirmek uygun olacaktır. Karatepe'nin dört, Erdoğan ve Gemici'nin üç, Türker'in iki ve Kaygusuz'un bir öyküsünde kadın anlatıcı kullanılmıştır.

Karatepe, "Duvar" ve "Dönemeç" öykülerinde; Oğuz ise Hab’taki tüm öykülerde ergen kızları anlatıcı olarak seçmiştir. Genç kadın ise Karatepe'nin "Aramızda”, "Ayna”, "Loş” öyküleriyle, Türker'in "Boş Mermer Yazıları” öyküsünde yer alır. Karatepe, çocuk anlatıcıyı sıklıkla kullanır. Dört öyküsünde küçük çocuk anlatıcıdır. İkinci sırada Türker ile Gemici ikişer öykü ile yer alır. Ayrıca Hah kitabındaki ergen kızın çocukluğu da buraya dâhil edilebilir. Kaygusuz ise daha çok anlatıcı yazar pozisyonunda kendini konumlandırmış ve diyaloğa girildiği vakit kadına ve kız çocuğuna sözü teslim etmiştir.

Erkeğin anlatıcı olduğu öykülere bakılınca Türker'de dört, Gemici ve Karatepe'de iki örnek bulunur. Oğuz ve Erdoğan hem öykülerinin bütünlüklü yapısı hem de anlatılanın ergen ve kadın figüre yaslanması dolayısıyla erkek anlatıcıya uzaktırlar. Buna göre elli dokuz öyküde; yirmi iki yazar, on dört kadın, sekiz erkek, dört genç kadın, üç ergen ve dokuz çocuk anlatıcı seçilmiştir. Yazarların anlatıcı tercihlerinde hem yazar olarak kendilerine hem de 
kadın anlatıcıya daha çok yer vermeleri, sosyal ve bireysel gelişimi destekleyen kurgusal düzeydeki verilerdir.

\section{Sonuç}

Kültürel ve sosyolojik değişmeler, postmodern gelişmeler kadın yazarın önceki dönemlerin çekingen, tanımlanmış konuşma biçimlerinden daha rahat, kendisine mahsus bir dile geçmesine yardımcı olmuştur. Kadın yazar sayısındaki artış, şehirleşme kadar eğitim, basım yayın imkânlarının gelişmesi ile de bağlantılıdır. Meryem'in "beden" alt başlığında ele alınan tespitiyle, bir önceki kuşakta yer alan kadınlar yeni kuşağın anlatabilme cesaretini arttırmıştır. Buna bağlı olarak incelenen öykülerde kadın yazar, bedenini daha rahat fakat ölçülü bir dile dökmüştür. Cinsellik açısından da dil erotizme teslim edilmemiştir. Edebi dilin sınırları içinde ve hatta alaycı (Meryem), yer yer de acıklı ve protest (Erdoğan, Türker) bir cinsellikten söz edilmiştir.

Kadın öykücüler, kendilerini tanımlayan veya öyle kabul gören merhamet, şefkat duygularını anlatırken iç konuşmalara yoğunluk vermişlerdir. Doğallıkla kadının duygusal dünyasını kısmen alışkanlık, kısmen değişen sosyolojiyle aktarmışlardır. Hatta geleneksel çocuk üzerinden anlatımda bile kendi süreçlerini izlemek mümkündür. Çocuğu acının ve çaresizliğin değil, yaşayabilmenin aracı, umudu ve bazen sevimli isyanı olarak konuşturmuşlardır. Özellikle sanal dünya ile değişen kültür alışkanlığı, bilgi perspektifi, karşı çıkmaya, yeni bir dile doğru evrilmektedir. Bütün bu bilgiler, kadın öykücülerin kendilerini ve dünyalarını anlatma cesaretlerinin arttığını ve bunu kendilerine mahsus bir dille yansıtabildiklerini ortaya koymaktadır. 


\section{Kaynaklar}

Ağaoğlu, Adalet (1993). Karşılaşmalar, İstanbul: Yapı Kredi Yayınları.

_ (2004). Yüksek Gerilim, İstanbul: Alkım Yayınları.

(2007). Damla Damla Günler III 1983-1996, İstanbul: Türkiye İş Bankas1 Kültür Yayınları.

Akerson, Fatma Erkman, der. (2013). Edebiyatımızda Bireyselleşme Serüveni, İstanbul: Ayrintı Yayınları.

Argunşah, Hülya (2006). “Kadın Edebiyatı Üzerine”, Türk Edebiyatı 387, s.38-40.

Atasü, Erendiz (2006). “Kadın ve Duyarlık”, Edebiyatımızın Kadın Kalemleri, Ankara: Vadi Yayınları, s.335-339.

Benhabib, Şeyla (1999). Modernizm Evrensellik ve Birey: Çağdaş Ablak Felsefesine Katkılar, Çev. M. Küçük, İstanbul: Ayrıntı Yayınları.

Bingölçe, Filiz (2001). Kadın Argosu Sözlüğ̈̈, İstanbul: Metis Yayınları.

Connor, Steve (2001). Post-modernist Kültür Çağdaş Olanın Kuramlarına Bir Giriş, Çev. Doğan Şahiner, İstanbul: Yapı Kredi Yayınları.

Dündar, Leyla Burcu (2007). "Edebiyat Sosyolojisi Açısından Türk Öykücülüğü: 1990-2005”, Yayımlanmamış doktora tezi, Ankara: Bilkent Üniversitesi.

Eagleton, Terry (2004). Edebiyat Kuramı, Çev. Tuncay Birkan, İstanbul: Ayrıntı Yayınları.

Ercilasun, Bilge (1997). “Türk Edebiyatında Popülerlik Kavramı ve Başlıca Eserler”, Yeni Türk Edebiyatı Üzerine İncelemeler 1, Ankara: Akçă̆ Yayınları, s.421-449.

Erdoğan, Aslı (2009). Taş Bina ve Diğerleri, İstanbul: Everest Yayınları.

(Nisan 2011). "Edebiyat İnsan Acısından Kaçıyor”, Söyleşi: Berat Günçıkan, (Erişim tarihi: 23 Haziran 2013), <http://www.aslierdogan.com/roportajlar. asp? sid $=43>$.

Gemici, Mukadder (2011). Asla Pes Etme, İstanbul: Dergâh Yayınları.

Hazer, Gülsemin (2005). "Kadın Öykü Yazarının Bireysel ve Kurgusal Sorunları", Hece Öykü 8, s.45-55.

İlkkaracan, İpek, der. (2010). Emek Piyasasında Toplumsal Cinsiyet Eşitliğine Doğru $\dot{I} s$ ve Aile Yaşamın Uzlaştırma Politikaları, İstanbul: İTÜ BMT-KAUM.

Karaca, Nesrin Tağızade (2006). "Leylâ Erbil”, Edebiyatımızın Kadın Kalemleri, Ankara: Vadi Yayınları, s.195-203.

Karatepe, Mihriban İnan (2012). Aramızda, Ankara: Hece Yayınları.

_ (Mayıs 2012). “Mihriban İnan Karatepe'yle Söyleşi”, Söyleşi: Hale Öz Kaplan, (Erişim tarihi: 2 Nisan 2014), <http://www.edebistan.com/index.php/ edebistan/mihriban-inan-karatepe-ile-iki-soylesi/2012/06>.

Kaygusuz, Sema (2010). Sandık Lekesi, İstanbul: Doğan Kitap.

Meryem, Hatice (2012). Sinek Kadar Kocam Olsun, Başımda Bulunsun, İstanbul: İletişim Yayınları.

(2013). "Mutfak Dedikoduları ile Kocakarı Hikâyeleri Arasında Bir Ses Gezintisi”, Hece Öykü 56, s.78-81.

Moran, Berna (1991). “Aşık Hikâyeleri, Hasan Mellah ve İlk Romanlarımız”, Türk Romanına Eleştirel Bir Bakış 1, İstanbul: İletişim Yayınları, s.21-37.

Oğuz, Birgül (2012). Hah, İstanbul: Metis Yayınları. 
Parla, Jale (2004). “Kadın Eleştirisi Neyi Gerçekleştirdi?” Kadınlar Dile Düşünce Edebiyat ve Toplumsal Cinsiyet, Der. Jale Parla ve Sibel Irzık, İstanbul: İletişim Yayınlar1, s.15-34.

Tekeli, Şirin (1995). “1980’ler Türkiye'sinde Kadınlar”, 1980'ler Türkiyesinde Kadın Bakış Açısından Kadınlar, Haz. Şirin Tekeli, İstanbul: İletişim Yayınları, s.1550.

Türker, Sibel K. (2012). Ağula, İstanbul: Can Yayınları.

—_ (Kasım 2003). "Y'si Seyyar Yazar", Söyleşi: Nazan Özcan, (Erişim tarihi: 2 Nisan 2014), <http://www.radikal.com.tr/radikal2/ysi_seyyar_yazar-870699>. 


\begin{abstract}
Determinations on the Language of Women Authors in 2000s

In Turkish literature, the language of women writers has followed the footsteps of male writers for a long period of time. The dramatic increase in the number of women writers through the changes in cultural, sociological and economical life in 2000s has led to a period in which the discussion on whether women have been able to find their own unique language is quite reasonable. The focus of this paper is to describe the characteristics of women language in 2000's Turkish stories, and to detect whether they developed their own language. The other concern of the paper is to determine whether the women writers were able to make alterations in the way the language is used by breaking past habits. Moreover, books of seven women writers who are considered as the important figures of the time were examined. In addition, this article attempts to approach women language in the contexts of compassion and sexuality, and it aims at presenting to what extent women writers are able to describe the world and the human different than the ordinary language.
\end{abstract}

Keywords: Woman writer and language, women story writers, 2000s, compassion, sexuality 